\title{
All Change in the House? The Profile of Candidates and MPs in the 2015 British General Election
}

\section{Chrysa Lamprinakou ${ }^{1}$, Marco Morucci ${ }^{2}$, Rosie Campbell ${ }^{1}$ and Jennifer van Heerde-Hudson ${ }^{3, *}$}

${ }^{1}$ Department of Politics, Birkbeck University of London, Malet Street, Bloomsbury, London, WC1E 7HX;

${ }^{2}$ Department of Political Science, Duke University, Gross Hall, 140 Science Dr, Durham, NC 27708, USA;

${ }^{3}$ Department of Political Science, University College London, 29-31 Tavistock Square, London WC1H 9QU

* Correspondence: jennifer.hudson@ucl.ac.uk

Drawing on data from the Parliamentary Candidates UK project, we profile the socio-demographic characteristics of parliamentary candidates standing in 2015 and compare elected MPs to previous cohorts since 1979. We argue that the 2015 cohort of candidates largely resembles the archetypal candidate identified by Durose et al. (2013, Parliamentary Affairs, 66, 246-267). Despite smaller parties' campaign rhetoric of a 'new kind of politics', parties across the spectrum offer up very similar candidate profiles. We find a narrowing of occupational backgrounds, with fewer candidates and MPs from manual occupations, and an increasing percentage of candidates and MPs with a university education. Competition across the parties, particularly in terms of the selection of women and black and minority ethnic (BME) candidates, has positive consequences for the representativeness of Parliament. However, despite a record number of women and BME MPs elected, Parliament remains disproportionately white and male.

Keywords: Archetypal candidate, Sex, Race/ethnicity, Occupation, Descriptive representation, Political class

\section{Introduction}

In the run up to the 2015 general election, Jeremy Paxman argued that the campaign was a choice 'between one man who was at primary school with Boris Johnson and one man who was at secondary school with him - both of whom 
did PPE at Oxford'. ${ }^{1}$ Paxman's quip reflects a long-standing debate in political science around descriptive representation or the extent to which elected representatives resemble - in terms of sex, race/ethnicity, social class, age and educationthe public they purport to represent. The question 'who our representatives are' remains an important one for British politics, particularly as Britain's political class has come under increasing scrutiny and criticism in recent years (Oborne, 2007; Allen and Cairney, 2015), not least in response to the expenses scandal (Van Heerde-Hudson, 2014). ${ }^{2}$ Among the public, a growing anti-Westminster sentiment reflects a view that Britain's political class has become selfperpetuating and elitist (Riddell, 1993) and the occupants of the Westminster Village are increasingly out of touch, insular, and unable to understand the lives and concerns of 'ordinary' citizens (Hansard Society, 2012).

The political class critique is often tied to debates about descriptive representation-who is and should be-represented (Lovenduski, 2010; Carnes, 2012; Kenny, 2012)? Despite the parties' efforts to recruit a more diverse group of candidates in recent elections, particularly in terms of race and sex, research has shown that politicians are increasingly drawn from a narrow, privileged class (Criddle, 2010; Durose et al., 2011). The evidence points to the persistent presence of an 'archetypal' candidate - a white, middle-aged, male from a middle-class background. Where candidates do deviate from the norm, they tend to conform to the stereotype in other regards, namely in terms of their educational and occupational backgrounds (Durose et al., 2013).

The aim of this article is not to further the theoretical debate on descriptive representation, but to empirically examine the social profile of parliamentary candidates standing in the 2015 general election, motivated by two key questions. First, what is the social profile of candidates standing in 2015, and secondly, to what extent does the 2015 cohort of candidates resemble the archetypal candidate? We address these questions in three ways: comparing the social profile (sex, race, age, educational and occupational background) of who is selected (all candidates) with who is elected (MPs); comparing the social profile of candidates in parties' target seats; and comparing the social profile of the 2015 cohort of MPs to cohorts since 1979 .

The political context of the 2015 general election provides an excellent opportunity to consider the descriptive representation of parliamentary candidates for three principal reasons: first, a decline in support for Labour and the Conservatives since the 1970s (Särlvik and Crewe, 1983) and the concomitant rise in support for

\footnotetext{
${ }^{1}$ The Guardian, 'http://www.theguardian.com/media/2015/apr/28/jeremy-paxman-itv-take-me-outnever-watches-newsnight', 28 April 2015.

${ }^{2}$ This work sits within a larger, comparative literature (see e.g. Borchert and Zeiss, 2003) on the political class, with a focus on the UK House of Commons.
} 
smaller and national parties; secondly, efforts to increase the diversity of parliamentary candidates, particularly by Labour and the Conservatives; and thirdly, concerns over the rise of career politicians and the professionalisation of politics. We take up each of these briefly.

The smaller parties' challenge to the traditional two-party system did not emerge overnight. The 2015 election followed on the heels of the first post-WWII formal coalition, and with the overwhelming majority of polls predicting a hung Parliament, expectations were that the 2015 outcome would produce a second peacetime coalition or minority government. In the end, the polls turned out to be very poor predictors of the vote in England and of the overall outcome (Sturgis et al., 2016). And, contrary to historical trends and expectations, the percentage of the vote secured by the two main parties, Conservative and Labour, increased from $65.1 \%$ in 2010 to $67.2 \%$. However, the collapse of the Liberal Democrat vote and surges by the Scottish National Party (SNP) and UK Independence Party (UKIP) resulted in a greater distribution of the vote share among the smaller parties, but with significantly different results in terms of seats. ${ }^{3}$ Thus, despite a return to majority government in 2015 , few would argue that the landscape of British politics has not shifted markedly.

Some of the electoral appeal of smaller parties-particularly UKIP, SNP and Greens-was the result of running on 'anti-Westminster', 'anti-establishment' platforms offering themselves up as an alternative to 'business as usual'. But did the smaller parties offer more than just different policies? But did candidates from the smaller parties look at all different to candidates from the three main political parties? Did they increase the diversity of parliamentary candidates or do they too conform to the norm of the archetypal politician?

Secondly, the 2015 general election took place among growing debate and interparty recognition of the under-representation of specific subgroups of the population in Parliament, particularly women and members of black and minority ethnic (BME) communities (Norris and Lovenduski, 1995; Lovenduski, 2010; Sobolewska, 2013; Campbell and Childs, 2015). There has been considerable variation within parties with respect to improving the diversity of their candidates. The Labour Party has been proactive in this regard through their use of allwomen shortlists (AWS), a form of quota, since 1997. This has resulted in a stepchange for women's representation in the Parliamentary Labour Party and in the Commons more generally. However, since David Cameron's election as Conservative Party leader in 2005, the Conservatives have made efforts to secure

\footnotetext{
${ }^{3}$ In 2015, the Liberal Democrats secured 7.9\% of the vote, UKIP $12.6 \%$ and the SNP 4.7\%. The majoritarian, winner take all system resulted in 56 SNP MPs elected to Westminster, 50 more than in 2010, making the SNP the third largest party in the House of Commons. UKIP came second in 120 constituencies, but only managed to maintain a single MP, Douglas Carswell.
} 
significant improvements in the diversity of its benches, albeit through less formal mechanisms (Childs and Webb, 2012). ${ }^{4}$

Furthermore, the Speaker's Conference on Parliamentary Representation (2010) helped to foster an environment where all of the parties represented in Westminster have been publicly called to account for the under-representation of specific social groups (House of Commons, 2010). Arguably there is a consensus among the Westminster parties that increasing the diversity of the House is a 'good thing' (Campbell, 2016), although there is disagreement among the parties about the mechanisms that should be deployed to achieve the goal (Cairney et al., 2015).

Finally, the issue of the under-representation of women and members of BME communities in British politics runs parallel to concerns about the growth of career politicians, the professionalisation of politics (Best et al., 2001, Cairney, 2007; Mattozzi and Merlo, 2008) and the resulting under-representation of members of the working class (Norris and Lovenduski, 1995). The decline of workingclass, trade union-backed Labour MPs and aristocratic Conservative MPs has led to the rise of the career politician (King, 1981; Riddell, 1993, 1995). In the past, the most prominent career path for MPs was through 'brokerage' occupations such as law and education. These professional occupations provided candidates with skills and knowledge as well as local networks, which later facilitated their entry into politics (Cairney, 2007).

More recently, there has been a rise in 'politics-facilitating' occupations as a path to a political career, for example, working as a parliamentary researcher, special advisor, party official or full-time local councillor (Cairney, 2007, p. 214; Allen and Cairney, 2015). With established links to politics and particularly to Westminster, politics-facilitating occupations provide a key route into Parliament for an increasing number of politicians (Cairney, 2007; Allen, 2013). However, the majority of candidates are drawn from the middle-class occupations in the professions (law, medicine, education) and other white-collar backgrounds (Norris, 1997; Best and Cotta, 2000; Jun, 2003).

One consequence of the professionalisation of politics then, is the convergence towards a stereotypical or archetypal candidate (Durose et al., 2013). Professionalisation has resulted in a lowering in the average age of MPs first entering Parliament, higher levels of educational attainment (especially in subjects related to politics) and a narrowing in the previous occupational experience of

\footnotetext{
${ }^{4}$ Delivering on David Cameron's promise to transform the Conservative Party, the Conservative Central Office drawn up an 'A-list'; that is, a 'priority' list of candidates for selection at open primaries, Conservative target and safe seats, for the 2010 general election. While not exclusive to women candidates, the A-list comprised a large number of women leading to an increase of 7\% in the number of Conservative women MPs in 2010.
} 
candidates. The choice of university, subject of study and early career of young, aspiring politicians is subject to the links they can establish with the inner circles of the Westminster village. In this article, we examine the extent to which the 2015 cohort of candidates conforms to the archetypal politician, and whether MPs elected in 2015 contribute to a more or less diverse Commons.

\section{Data and approach}

The data come from the Parliamentary Candidates UK (PCUK) project which analyses Britain's changing political class by collecting, among other variables, data on the socio-demographic profile of candidates and MPs since 1945. We profile parliamentary candidates for the 2015 general election for candidates from Labour, Conservative, Liberal Democrat, Scottish National, Plaid Cymru, UKIP, Green and Northern Ireland parties. ${ }^{5}$

Collecting data on candidates is a difficult exercise as there is no single source of candidate data, either from the regulator (the Electoral Commission), or from the political parties themselves. Indeed, given the varying resources and professionalisation of internal party organisations, there are significant differences among the parties with respect to knowledge of their own candidates and their backgrounds. The Equalities Act $(2010)^{6}$ was an attempt to remedy a gap in the provision of data with respect to the diversity of parties' candidates, but by the 2015 general election, formal mechanisms to ensure parties complied failed to materialise, instead relying on a voluntary approach to releasing selection data (Kelly and White, 2016).

Once elected, however, data for MPs are more readily available, due in large part to the efforts of the House of Commons Library, academic research (Rush, 1994; Criddle, 2010; Nuffield Election Guides), public affairs (DODs) and public interest organisations (TheyWorkforYou.com; YourNextMP.com). These data are limited, however, in terms of the range of variables collected or by their form (i.e. in hard copy as almanacs or fact books).

To compile the data set we relied on publicly available data from a range of sources including local/national newspapers; party, candidate and electionrelated websites; social media outlets (Facebook, Twitter); and historical data/ texts. Starting from the point of selection for new candidates or reselection for MPs standing again, we collated information from the various sources iteratively building a profile for each candidate as information emerged. Thus, we revisited

\footnotetext{
${ }^{5}$ We collect information on independent candidates if they are one of the top two finishers in a constituency.

${ }^{6}$ See, for example, Section 106, Equalities Act 2010.
} 
available data for each candidate several times-before, during and after-the election campaign.

There are two limitations to reliance on publicly available data, both related to sources of 'missingness' in the data. ${ }^{7}$ First, there is simply less information on candidates from smaller parties in the public domain. This may due to smaller parties lacking the infrastructure and resources to publicise their candidates (e.g. via candidate or party websites) or because many candidates from smaller parties are 'paper candidates', that is, candidates selected to ensure a party's presence on the ballot but who stand no real chance of winning. Given their surge in electoral support in the run up to the short campaign, both UKIP and the Green Party were keen to stand candidates in each of the 650 Westminster constituencies, but many of these candidates were selected quite late and with no intention to run a genuine campaign.

A second source of missingness comes from what candidates choose to put into the public domain, and candidates have incentives to make public those attributes deemed more attractive by the electorate. For example, recent research shows that voters prefer candidates who are local above any other trait (Campbell and Cowley, 2014). This creates an incentive for candidates to claim local connections, however tangential, such as a grandmother born in constituency or renting accommodation during the campaign to show a 'local' address, for example. Candidates are equally incentivised to hold back information that is not electorally valuable, for example, being a 'Westminster insider'. Both sources of missingness produce potential biases in our results, which we discuss in Section 3 below. ${ }^{8}$

We profile candidates standing in 2015 across five key variables-sex, race/ethnicity, education, occupation and age-comparing who is selected (all candidates) with who is elected (MPs); comparing the social profile of candidates in parties' target seats; and comparing the social profile of the 2015 cohort of MPs to cohorts since $1979 .{ }^{9}$ Sex and race/ethnicity are binary measures. Although a more detailed

\footnotetext{
${ }^{7}$ An alternative approach would be to survey candidates and ask explicitly for this information or otherwise use data from confidential surveys, but declining survey response rates mean that effect research requires both strategies.

${ }^{8}$ The percentage of missing data for the educational and occupational background of candidates is higher than that for MPs. We have no missing data for MPs on occupation, but $28 \%$ missing for all candidates from all seven parties. The per cent missing for candidates for education is: school $=65 \%$; university $=45 \%$; Oxbridge $=50 \%$; the per cent missing for MPs is $11 \%, 2 \%$ and $2 \%$, respectively. We note that the increased rate of MPs school-type is mainly due to the lack of information for the new cohort of SNP MPs.

${ }^{9}$ Our measure of target seats for Conservatives, Labour, Liberal Democrat, Plaid Cymru and the SNP use two measures: whether there was $\leq 10 \%$ difference in vote share between the first and second parties (similar to BBC) and whether the party was second in the constituency at the 2010 general election.
} 
measure of race/ethnicity is preferable, it remains for candidates to self-identify, and given that few do publicly, the binary measure remains the most valid. We measure three dimensions of candidates' educational background: the type of school they attended (state or privately funded), whether they have a university education and whether they are graduates of Oxford or Cambridge universities. For the analysis of candidates' occupational background, we consider their occupation immediately prior to election and code it as 'brokerage' (e.g. legal profession, civil service), 'instrumental' (e.g. party official, special advisers (SPADS)), 'business' (e.g. private sector employees or company owners), 'manual' and 'other' (Cairney, 2007).

\section{Analysis}

\subsection{The social profile of 2015 candidates}

In this section, we compare the social profile of candidates across the parties and by winners and losers. We then disaggregate the data to tell a more nuanced story about differences between the selected and elected. Table 1 shows the social profile of 2015 parliamentary candidates by party. Looking across the categories, it is clear that candidates do not descriptively represent the population they serve in certain key demographics. Moreover, the profile of candidates from smaller or 'outsider' parties do not look measurably different from the main parties, with some exception for educational background.

Evidence for a narrowing of the political class can be observed by looking at the percentage of candidates who are university educated. Overall, $84 \%$ of parliamentary candidates were educated to the degree level (or higher), which compares to $30 \%$ in the UK population. ${ }^{10}$ UKIP had the highest percentage of candidates who did not attend university at 35\%, followed by SNP candidates at 23\%. These parties differ from the Conservatives and Labour with 15\% and the Liberal Democrats with just $12 \%$ of candidates educated at the degree level. However, we apply some caution to the UKIP figure as the party fielded a large number of 'paper candidates' in an attempt to contest every constituency in 2015. Many of these candidates had no expectation of winning and many provided little to no information about their candidacies.

The marginality measure gives an indication of where a seat may change hands and 'party second' allows us to determine whether the party actually stands a chance at winning the seat. For UKIP and Greens, this criteria does not apply given their results in 2010. Here we used their stated target seats, so their judgment of whether they are competitive for a seat. Our measure does not pick up three-way marginals.

\footnotetext{
${ }^{10}$ Office of National Statistics; data from 2011 Census. See http://webarchive.nationalarchives.gov.uk/ 20160105160709/http://www.ons.gov.uk/ons/rel/census/2011-census-analysis/local-area-analysis-ofqualifications-across-england-and-wales/sty-qualification-levels.html.
} 
Table 1 The social-demographic profile of 2015 parliamentary candidates by party

\begin{tabular}{|c|c|c|c|c|c|c|c|}
\hline & All & Con & Labour & Lib Dem & SNP & UKIP & Other \\
\hline \multicolumn{8}{|l|}{ Sex } \\
\hline Female & 27 & 26 & 34 & 26 & 36 & 13 & 36 \\
\hline Male & 73 & 74 & 66 & 74 & 64 & 87 & 64 \\
\hline \multicolumn{8}{|l|}{ Race/ethnicity } \\
\hline Non-white & 7 & 10 & 8 & 8 & 2 & 7 & 4 \\
\hline White & 93 & 90 & 92 & 92 & 98 & 93 & 96 \\
\hline \multicolumn{8}{|l|}{ Education } \\
\hline Non-fee paying & 74 & 57 & 87 & 73 & 94 & 77 & 79 \\
\hline Fee-paying & 26 & 43 & 13 & 27 & 6 & 23 & 21 \\
\hline No degree & 16 & 15 & 15 & 12 & 23 & 35 & 11 \\
\hline University & 84 & 85 & 85 & 88 & 77 & 65 & 89 \\
\hline Oxbridge & 19 & 29 & 18 & 17 & 0 & 6 & 11 \\
\hline Other & 81 & 71 & 82 & 83 & 100 & 94 & 89 \\
\hline \multicolumn{8}{|l|}{ Occupation } \\
\hline Business & 25 & 40 & 13 & 22 & 16 & 40 & 14 \\
\hline Manual & 1 & 1 & 2 & 1 & 2 & 2 & 2 \\
\hline Professions & 15 & 13 & 19 & 16 & 10 & 12 & 11 \\
\hline Other & 59 & 47 & 66 & 62 & 72 & 45 & 73 \\
\hline \multicolumn{8}{|l|}{ Age } \\
\hline $18-39$ & 27 & 24 & 27 & 28 & 26 & 21 & 36 \\
\hline 40-59 & 54 & 63 & 50 & 49 & 61 & 50 & 47 \\
\hline $60+$ & 19 & 12 & 23 & 23 & 12 & 29 & 17 \\
\hline
\end{tabular}

Source: PCUK 2015; $\mathrm{n}=3190$; numbers rounded to nearest percentage.

But it remains unclear how missing data for UKIP candidates bias our estimates here. Would, for example, complete data show a higher percentage of UKIP candidates having not attended university, the same percentage or a lower one? For all candidates for which we do have data, there is small and positive but insignificant relationship $(r=0.08)$ between educational level and constituency marginality, or no evidence that better educated candidates are in the more competitive constituencies. This is also true in looking at just UKIP candidates. For UKIP candidates in the party's target seats, there is a negative but still insignificant relationship. Thus, it is not clear that missing data is pushing up or down our estimates measurably.

With respect to occupational background, just $1 \%$ of candidates come from manual occupations, with few differences across the parties. ${ }^{11}$ There are party differences, however, with respect to 'other' and 'business' categories, but these

\footnotetext{
${ }^{11}$ The Office of National Statistics does not code for 'manual occupations' post 2013, however, breaking down occupation type from ONS sources, the percentage of the public in manual occupations in the UK is significantly higher than $1 \%$. See https://www.nomisweb.co.uk/reports/lmp/gor/ 2092957698/report.aspx, for example.
} 
differences are the result of 'large v. small' or 'insider v. outsider' party differences. On average, nearly six in ten candidates come from 'other' occupations, a broad category including party/trade union officials and civil servants, but is higher for the SNP (72\%), other parties (73\%) and Labour (66\%). We also see party differences in terms of candidates from backgrounds in business/commerce, significantly higher for both Conservative and UKIP candidates (40\%).

The data in Table 1 also confirm that the archetypal candidate is still very much in situ as 2015 candidates are predominantly male (73\%), white (93\%) and middle-aged (54\%). Over half of the 2015 candidates (54\%) were aged between 40 and 59 at the time of election, though this was significantly higher for the Conservatives $(63 \%)$ and SNP (61\%), but both of whom had the lowest percentage of candidates aged $60+(12 \%)$. Again, there are differences across the parties in terms of the sex and race/ethnicity profile of candidates, but it is not the case that smaller parties are more representative in this regard. The SNP had the highest percentage of women candidates $(36 \%)$ of the five main parties we examined, 15 followed by Labour (34\%) and both the Conservatives and Lib Dems with 26\%. UKIP had the lowest percentage, with just $13 \%$ female candidates. None of the parties fielded BME candidates equivalent to the population (13\%), although Conservatives came close with 10\%. Even within Scotland where the ethnic minority population is just 4\%, the SNP fielded $2 \%$ BME candidates.

But are there differences in the social profile of candidates who are selected and who are elected? In other words, are there some social attributes that are more likely to characterise winners rather than losers? The data in Table 2 suggest that there are few meaningful differences across sex, race/ethnicity, university education and occupation, but winners-MPs - are more likely to have attended fee-paying schools and attended Oxbridge. Winners are also more likely to be middle-aged (40-59) and losers younger (18-39).

Disaggregating the data, we can get a better sense of which kinds of women and ethnic minority candidates are selected and elected. Previous research has shown that women candidates tend to be older and better educated than their male counterparts (Norris and Lovenduski, 1993; Carroll and Sanbonmatsu, 2013), particularly as women wait longer to stand for office due to family and caring responsibilities. Our data confirm the latter, but not the former. Women candidates $(87.4 \%)$ were more likely to be university educated than men $(82.6 \%)$, as were women MPs $(86.4 \%)$ compared to men MPs $(81.5 \%)$. However, our data show that women candidates $(46.4 \%)$ were younger, on average, than their male counterparts $(50.1 \%) .^{12}$

\footnotetext{
${ }^{12 ،}$ Missingness' for candidate age is ca. 50\%, driven largely by 'paper' UKIP and Green Party candidates. UKIP's candidate profile was older and the Green's was younger, on average. This may affect the average age for candidates, but it does not affect MP age, where data is complete.
} 
Table 2 The social-demographic profile of 2015 parliamentary MPs (winners) and candidates (losers)

\begin{tabular}{llc}
\hline 2015 candidates & Losers (candidates) & Winners (MPs) \\
\hline Sex & & \\
$\quad$ Female & 26 & 29 \\
$\quad$ Male & 74 & 71 \\
Race/ethnicity & 8 & 6 \\
$\quad$ Non-white & 92 & 94 \\
$\quad$ White & & \\
Education & 78 & 70 \\
Non-fee paying & 22 & 30 \\
Fee-paying & 16 & 17 \\
No degree & 84 & 83 \\
University & 14 & 26 \\
Oxbridge & 86 & 74 \\
Other & & 26 \\
Occupation & 25 & 1 \\
Business & 1 & 17 \\
Manual & 14 & 57 \\
Professions & 60 & 16 \\
Other & & 64 \\
Age & 35 & 20 \\
18-39 & 46 & \\
$40-59$ & 19 & \\
$60+$ & & \\
$n=3190$ & & \\
\hline
\end{tabular}

Source: PCUK 2015; numbers rounded to nearest percentage.

There are notable party differences in the profile of women candidates. SNP and UKIP candidates were less likely to have a university degree compared to women candidates from all other parties and also less likely to have attended Oxbridge. The two parties also selected a lower percentage of BME women. Women candidates are almost exclusively middle class, as defined by their occupation at the time of the election, with Conservative and UKIP women candidates were more likely to be recruited from business backgrounds. ${ }^{13}$ And, no more than $2 \%$ of women candidates came from manual occupations for any of the parties.

As shown above, women candidates were no less likely to be elected compared to their male counterparts, but what about for BME women candidates? The data show that BME women were elected at rates equal to white women and more likely to be elected compared to BME men. But there are differences among BME

\footnotetext{
${ }^{13}$ The Nuffield studies use formative occupation as a measure of class; we, however, use occupation at the time of election as this provides better coverage for candidates/MPs over time.
} 
candidates in terms of who is selected and elected with regard to educational background. Attending fee-paying schools, university and Oxbridge is disproportionately higher for BME MPs than for BME candidates suggesting some evidence for Durose et al.'s (2013) 'acceptable difference' thesis.

\subsection{The social profile of candidates in parties' target seats}

In the previous section, we show that candidates standing in 2015 largely conform to characteristics of the archetypal candidate, albeit more representative with respect to sex and race/ethnicity. However, a more diverse group of parliamentary candidates will not impact the social profile of the Commons if diverse candidates stand in constituencies where they have little to no chance of winning. Here, we look at the social profile of candidates in parties' target seats, analysing similarities and differences across the parties. ${ }^{14}$

The occupational background of candidates in target and non-target seats differs across the three main parties. ${ }^{15}$ Labour and Lib Dems have a higher percentage of candidates from 'instrumental' occupational backgrounds, compared to the Conservatives, and this difference is magnified when we disaggregate by target seats. As shown in Figure 1, 44\% of Lib Dem and 43\% of Labour candidates in target seats come from 'politics-facilitating' backgrounds. In contrast, a plurality of Conservative candidates (44\%) come from business and commerce backgrounds, with only $18 \%$ of candidates in target seats from instrumental occupations. As for the other occupational categories, percentages remain very similar across target and non-target seats, but vary by party: Labour and Lib Dems tend to have a higher percentage of candidates with a non-traditional occupation (coded as 'other') with respect to Conservatives, while all three parties have somewhat similar percentages of candidates with brokerage occupational backgrounds.

As shown above, nearly one of five university-educated candidates attended either Oxford or Cambridge, but is there any evidence that Oxbridge candidates stood in parties' target or winnable seats? As a group, were these candidates 'privileged' compared to non-Oxbridge contenders? ${ }^{16}$ The data in Figure 2 show no consistent privilege for Oxbridge alums. For both Labour and the Conservatives, a lower percentage of candidates with Oxbridge educations were selected in target

\footnotetext{
${ }^{14}$ The data here do not allow us to speak directly to parties' selection strategies, either national or local; we observe only the type of seat candidates have been selected in.

${ }^{15}$ We limit our analysis to the three main parties in Figure 1 due to extensive missing data for UKIP, Green and SNP candidates.

${ }^{16}$ We do not compare parties' university-educated candidates in target and non-target seats as $84 \%$ of candidates are university educated.
} 


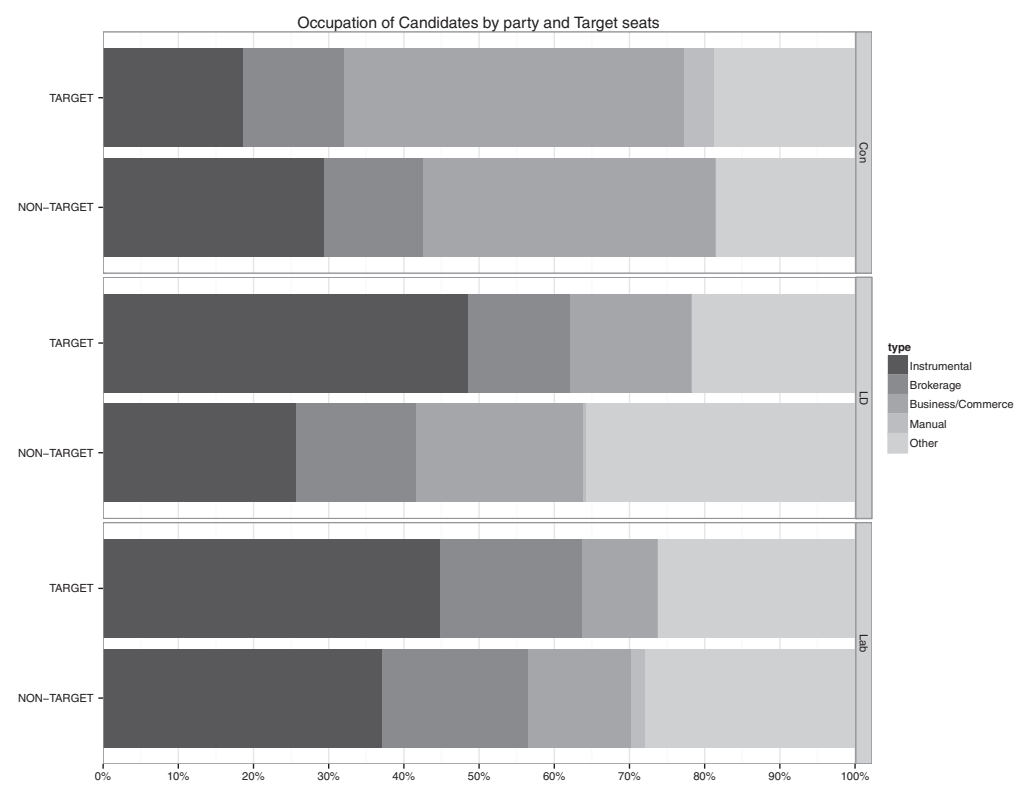

Figure 1. Occupation by party and target seats.

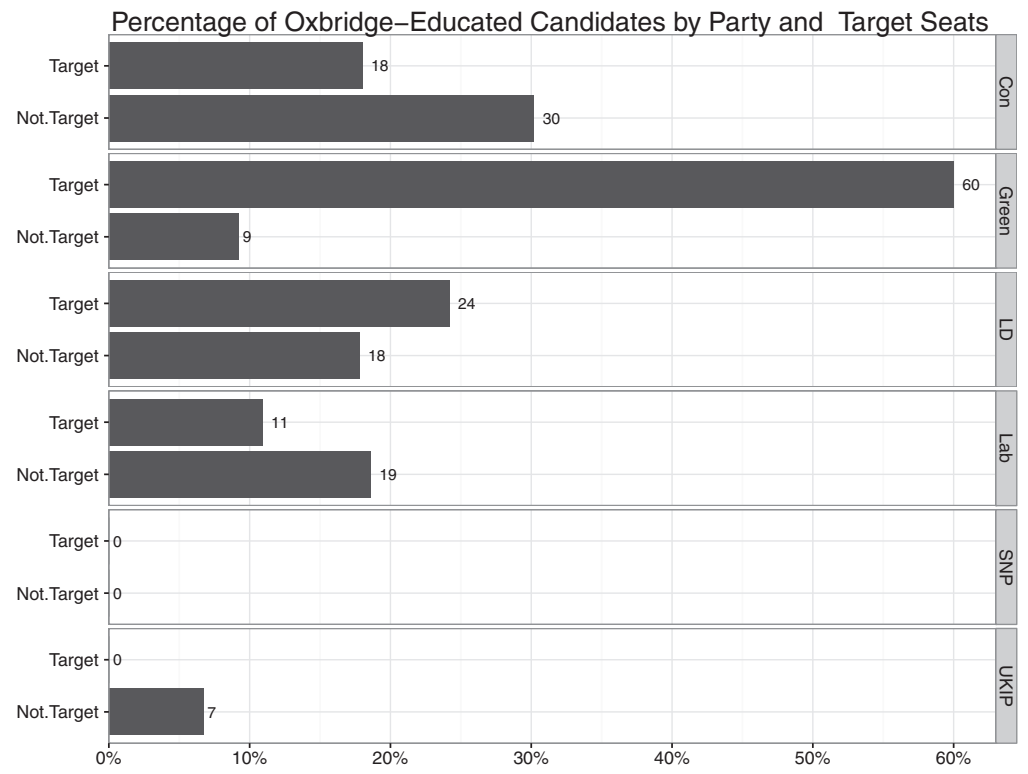

Figure 2. Percentage of Oxbridge-educated candidates by party and target seats. 
seats than non-target seats. For the Conservatives, $18 \%$ of candidates with Oxbridge degrees were in target seats compared to 30\% in non-targets. For Labour, the figures are $11 \%$ and 19\%, respectively. However, the opposite was true for Liberal Democrat and Green Party candidates where a higher percentage of Oxbridge alums stood in the parties' target seats than did not. We interpret the $60 \%$ figures for Green candidates with some caution given the small number of target seats for the party. Turning to the UKIP and the SNP, which have the lowest percentage of university-educated candidates at $65 \%$ and $77 \%$, respectively, candidates from these two parties were also less likely to have attended Oxbridge than candidates from the other parties. Within their target seats, just 7\% of UKIP candidates attended Oxbridge. Under our definition of target seat, none of the 59 Scottish constituencies qualify, but it is interesting to note that not a single SNP candidate attended Oxbridge-having been educated, almost exclusively_at Scottish universities.

Parliamentary candidates with an Oxbridge education are still significantly over-represented compared to the wider UK population: 19\% of candidates have Oxbridge degrees compared to just $1 \%$ of the population. Again, our data do not allow us to say whether the distribution of Oxbridge-educated candidates is the result of any kind of articulated strategy by the parties, but in the aggregate there is no evidence in 2015 that they were systematically privileged by standing in the parties' most winnable seats.

Turning to women's representation, Labour's ongoing use of AWS resulted in the second highest number of women candidates selected overall, but the highest percentage — by some margin—of women candidates in target seats. ${ }^{17}$ As shown in Table 3, women candidates stood in 52\% of Labour's target seats, followed by the SNP who selected women in $36 \%$ of their 59 seats. The Liberal Democrats had more than a third of women in their target seats (35\%) but their electoral disaster left them with just eight male MPs. Historically, the Liberal Democrats have tended to place men in safer seats than women (Campbell and Lovenduski, 2005; Campbell and Childs, 2010) and this is probably the best explanation for why the residual Lib Dem MPs are all men. The Conservative Party selected women in $28 \%$ of their target seats, an improvement on their historical record, but still considerably behind the other parties. UKIP was by far the least equal party with just $13 \%$ women candidates overall and $20 \%$ women in their target seats.

The 2015 general election was a step-change for ethnic minority representation in the Commons. There are now 41, or 6\% BME MPs, the highest percentage to date. However, the 2015 increase is a function of the steps taken and strategies employed in the 2010 general election by parties and candidates alike.

\footnotetext{
${ }^{17}$ Winnable seats could be either marginal seats or inherited safe seats.
} 


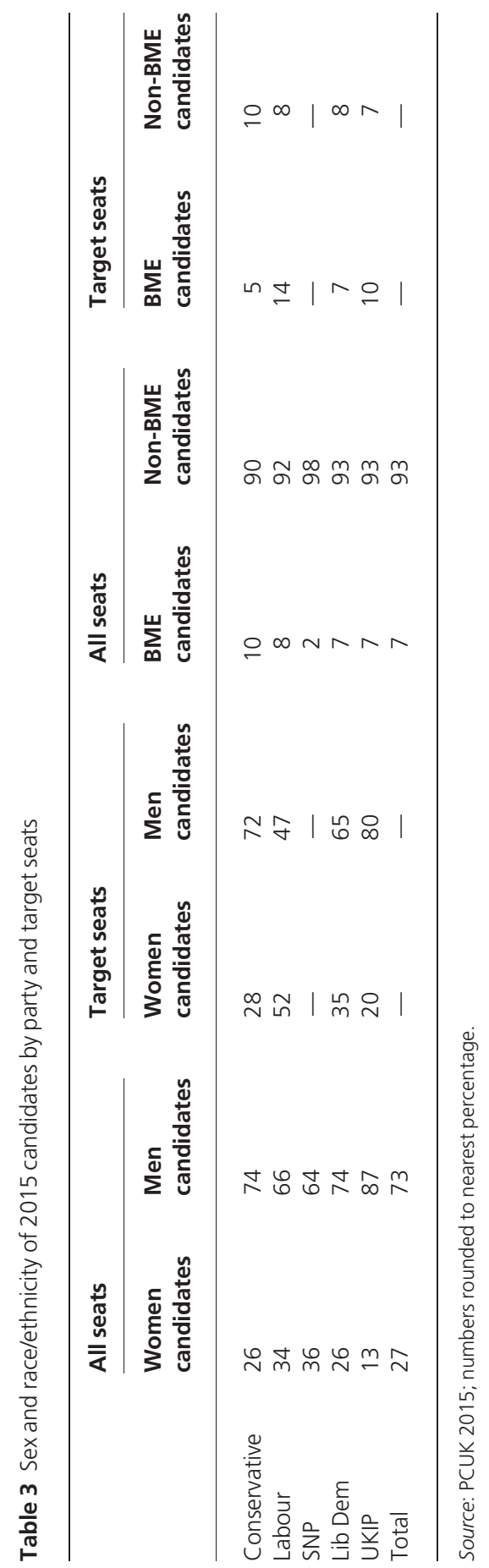


Sobolewska (2013) argues that the increase in the number of BME MPs can be attributed to the unusual opportunity structure of the 2010 electoral context. On the one hand, there was the 'opportunity' created by the record number of retiring incumbents and thus a high number of new MPs. On the other hand, the three main parties were publicly committed to responding to the challenge of under-representation (House of Commons, 2010). The Conservatives wanted to signal a modern party image, while Labour and the Lib Dems wanted to win back ethnic minority voters.

In 2015, 7\% of candidates standing in the 2015 general election were from black or minority/ethnic backgrounds. The Conservatives fielded the highest percentage of BME candidates (10\%), followed by Labour and the Lib Dems (8\%), UKIP (7\%) and the SNP (2\%). But did 2015 BME candidates stand in unwinnable seats? Research has shown that while the percentage of BME candidates selected has steadily grown, BME candidates are often selected in unwinnable seats. Kulich et al.'s (2014) evidence suggests that in the last three UK general elections, seats contested by ethnic minority candidates were harder to win than those seats contested by white candidates.

Mirroring our findings for women candidates, the parties differed not only in the percentage of BME candidates selected, but whether the candidates were placed in winnable seats. Table 3 shows that although the Conservatives selected the highest percentage of BME candidates overall, it was Labour again with a better record or BME candidates in target seats: 14\% BME candidates stood in Labour targets compared to 5\% for the Conservatives. However, disaggregating this further, Labour's BME women were still less likely to be selected in target seats $(39.1 \%)$ compared to BME men $(43.8 \%)$, but more likely than white women $(36.6 \%)$ and white men $(25.3 \%)$ candidates.

Labour increased their number of BME MPs from 16 to 23 in 2015, despite performing weaker than projected in pre-election polls, illustrating the importance of where candidates stand. With just 5\% BME candidates in target seats, the Conservatives also increased their number of BME MPs in 2015 to 17, up from 11 in the 2010 general election. With the highest percentage of BME candidates overall, but the lowest in target seats, how did the Conservatives make such gains? Part of the reason is their better than expected results, but they also selected candidates in other winnable seats—safe, Conservative retirement seats-where 7 of 38 retirement seats were filled by BME candidates. In so doing, they virtually guaranteed the election of James Cleverley (Braintree), Suella Fernandes (Fareham), Nusrat Ghani (Wealden), Ranil Jayawardena (Hampshire North East) and Rishi Sunak (Richmond), all whom enjoyed majorities of more than $30 \%{ }^{18}$

\footnotetext{
${ }^{18}$ Safe retirement seats measured where there is a $>10 \%$ difference in vote share between the 2010 first and second place vote and the party's incumbent has stood down.
} 
Taken together, these findings suggest that many of the gains in the diversity of the Commons in terms of sex and race/ethnicity is a consequence-either actively or passively — of the party's selection strategies. Despite these gains, the Commons remains unrepresentative in terms of race/ethnicity and sex. And where candidates do diverge from the norm of the archetypal candidate (Durose et al., 2013), they conform on other traits, that is, university educated, older and from a middle-class background. To illustrate, and taking just one possible cut of 'difference', of the 7\% BME candidates standing in 2015, 67\% were male, $89 \%$ have a university degree, $48 \%$ were between 40 and 59 years of age and all come from a non-manual occupational backgrounds.

\subsection{All change in the House? The social profile of MPs since 1979}

Finally, we examine how the cohort of MPs elected in 2015 changes the social profile of the House of Commons. Has the supply of a more diverse pool of candidates measurably changed the descriptive representation of MPs in Parliament? As shown in Figure 3, analysis of the 2015 MP cohort shows the continuation of four key trends with respect to occupational background since 1979. First, a decline in the percentage of MPs from manual backgrounds. Secondly, a decline in the percentage of MPs from the 'professions', for example, law, medicine, education, etc. Thirdly, an increase in the percentage of MPs with backgrounds in business/commerce, which maps onto the Conservative Party's electoral fortunes: a small increase from 1979 with Thatcher's triumph over Callaghan; a measurable decline in 1997 with Blair's New Labour win; and an increase in 2010 with the Conservative's in Coalition with the Liberal Democrats.

Fourthly, we see a significant jump in the percentage of MPs from 'other' occupational backgrounds. Although this increase reflects a trend since 1979, we apply some caution in interpreting this data. For purposes of historical comparison, our data have been coded to match the MP data by party from McGuinness (2010), which means that occupations that do not fall neatly into the manual, profession and business/commerce categories, we have coded as 'other'. One consequence is that this category may be artificially inflated, but more substantively, we expect some of the increase in the 'other' category may also reflect the trend for MPs from 'instrumental' occupations or previous jobs with direct links to politics (e.g. SPADs, parliamentary researchers, party officials, political researchers etc.) (Cairney, 2007). We also use measure occupation at the time of election, rather than formative occupation, which may be reflected in the figures for 'instrumental' occupations.

Figure 4 compares the educational background of Conservative, Labour and Liberal Democrat MPs and shows how the 2015 cohort of MPs reflects trends 


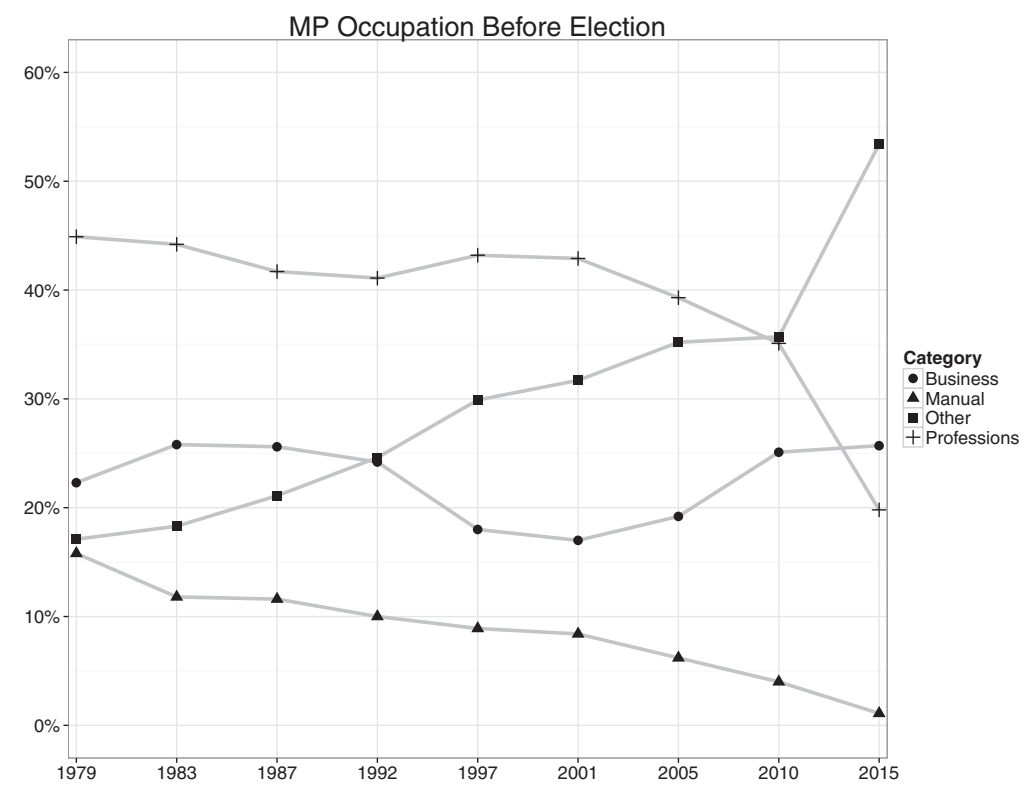

Figure 3. MP occupation prior to election, 1979-2015.

since $1979 .{ }^{19}$ First, the notable decline in the percentage of MPs attending feepaying schools, particularly for Conservative and Liberal Democrat MPs. In 1979, $73 \%$ of Conservative MPs attended fee-paying schools; by 2015 , only $46 \%$ of MPs had. The Lib Dems have experienced a similar decline, now with just one of their eight MPs having attended a fee-paying school (Nick Clegg). The percentage of Labour MPs attending fee-paying schools has remained relatively constant, but decreasing from $18 \%$ in 1979 to $14 \%$ in 2015.

Secondly, across all three main parties the percentage of university-educated MPs has increased markedly. In 2015, 84\% of MPs were university educated, an increase on the six in ten MPs from the $1980 \mathrm{~s}^{20}$ This change is most dramatic for Labour and the Liberal Democrat parties, both for whom had less than $60 \%$ of MPs with university educations in 1979 , rising to well over $80 \%$ by 2015 . And thirdly, the percentage of MPs who attended Oxbridge has also steadily declined. The drop in the percentage of MPs attending Oxbridge universities, from a high of $51 \%$ in 1997 to $26 \%$ in 2015 , reflects changes in the social profile Conservative

\footnotetext{
${ }^{19}$ Historical data are available only for Conservative, Labour and Liberal Democrat MPs (McGuinness, 2010, House of Commons Library).

${ }^{20}$ Recent evidence showing that top jobs in Britain-in politics, the courts and the boardroom-are held by an Oxbridge-educated elite (Kirby 2016). This is particularly true for the Cabinet level positions (Van Heerde-Hudson et al., 2015), rendering politicians subject to charges of elitism that limit diversity for the top jobs and is unrepresentative of the wider public (Riddell, 1993).
} 


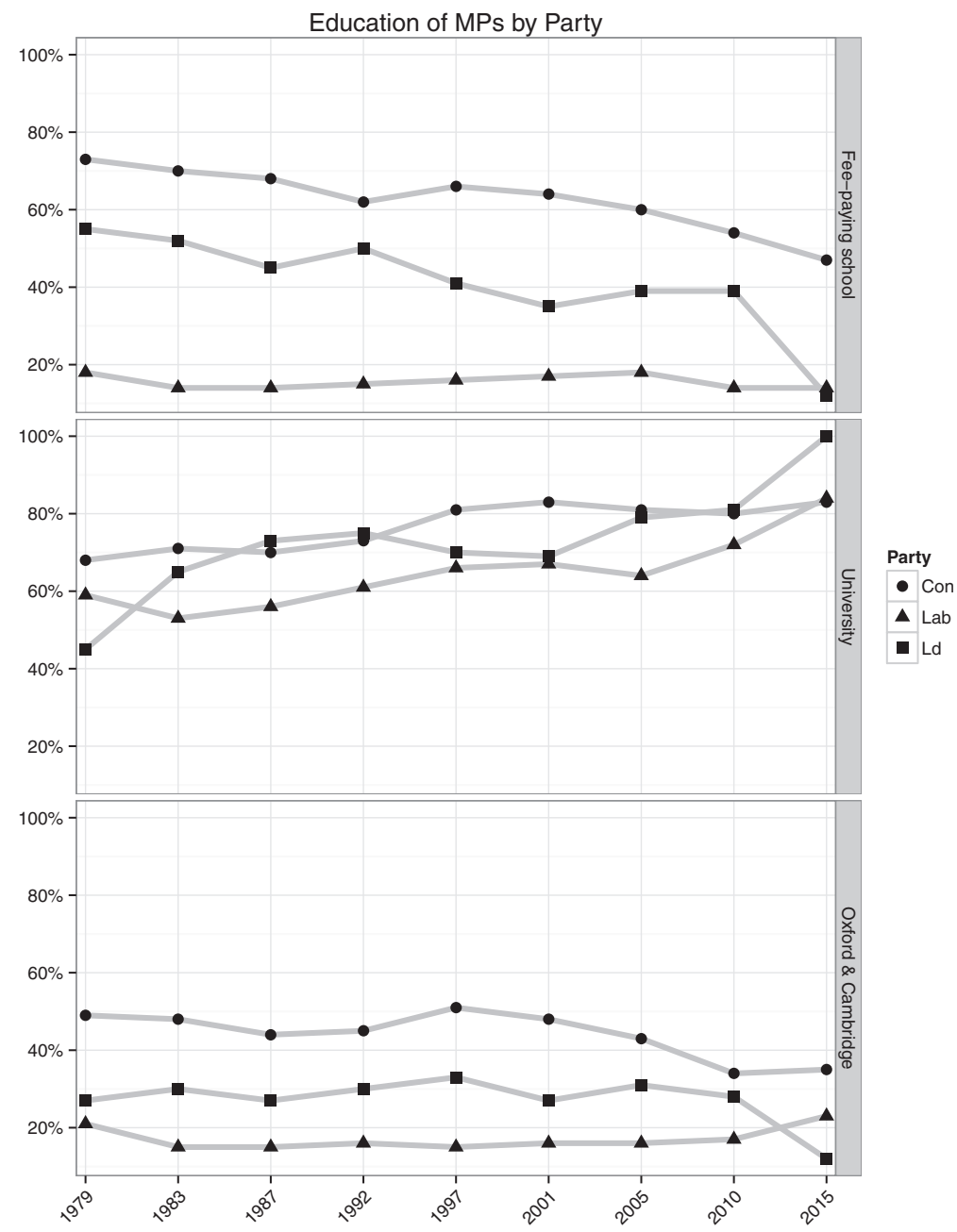

Figure 4. MP education by party, 1979-2015.

and Liberal Democrat MPs with the percentage of Labour MPs with Oxbridge educations holding constant over the period.

Figure 5 shows the percentage of women MPs from 1979 to 2015. As illustrated above, the parties' efforts to increase the percentage of women selected, and in winnable seats, has resulted in a significant increase in the percentage of women in the House, rising from 22\% in 2010 to $29 \%$ in 2015. The Conservative Party increased the percentage of women on their benches from $16 \%$ to $21 \%$, but the overall increase in women MPs was largely driven by Labour and the SNP, where the percentage of women in the parliamentary party increased from $31 \%$ 


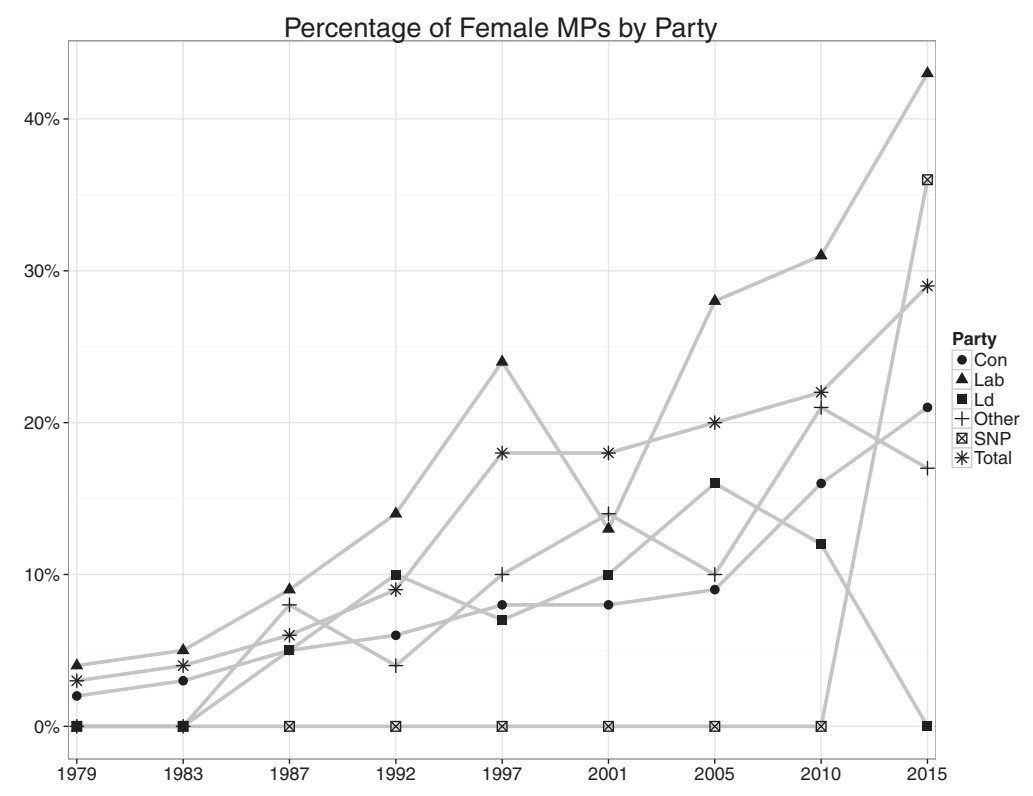

Figure 5. Percentage of female MPs by party, 1979-2015.

to $43 \%$ and from $0 \%$ to $36 \%$, respectively. As shown above, Labour's continued use of quotas in the form of all-women-shortlists and the high percentage of women in the party's target seats, has pushed the party further towards parity in Labour's parliamentary party.

The SNP did not use quotas in 2015, although they have recently voted to allow their use in future elections. Their landslide victory resulted in just three seats in Scotland not in SNP hands, creating an unprecedented situation where some SNP MPs had not even been party members prior to the referendum campaign in 2014. As such the election provided a unique opportunity for women candidates in Scotland to overcome both the incumbency disadvantage and entrenched party practices that discriminate against them in the rest of the UK (Mackay and McAllister, 2012).

Figure 6 shows the trend in BME MPs by party over time. Parliament did not have a single BME MP until 1987, when four were elected, all from the Labour Party. $^{21}$ Nearly two decades later, the number of BME MPs had risen to 15 in 2005, 13 of which were Labour MPs. It was not until Cameron's election as Conservative Party leader in December 2005 and his modernising agenda that the Tories started to take BME candidate recruitment and selection seriously. The

\footnotetext{
${ }^{21}$ Post-war BME MPs; the first ever BME MP was Dadabhai Naoroji elected in 1892.
} 


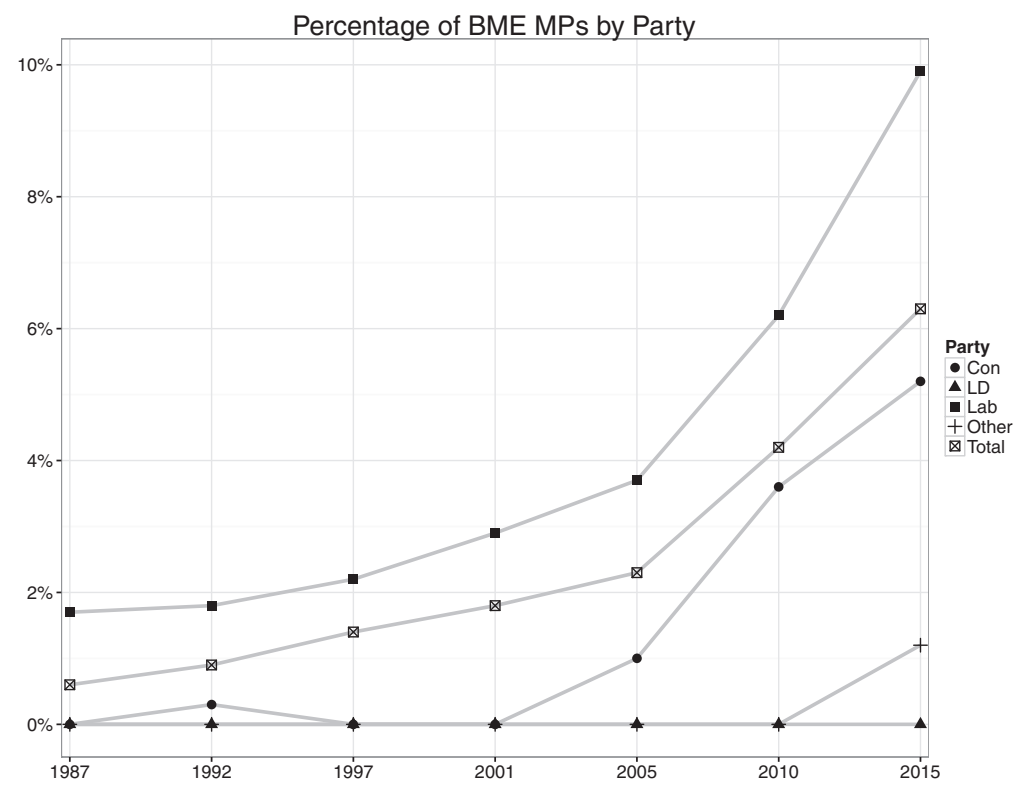

Figure 6. Percentage of BME MPs by party, 1979-2015.

results of both their and Labour's efforts were made clear in 2010, when 27 BME MPs were elected, and the Tories increased their BME MPs from 2 in 2005 to 11. Despite gains in BME representation in 2015, BME MPs make up just $6 \%$ of Parliament but $13 \%$ of the British population. To put the gains in perspective, it would take double the current number of MPs to achieve a descriptively representative Parliament.

Finally, we look at the average age of MPs at election since 1979. Another consequence of a more professionalised Commons is a shift in the age at which MPs begin their political and parliamentary career. King (1981, p. 263) has shown that from 1945 to 1979 the percentage of MPs first elected in their 30s has increased from $31.4 \%$ for the 1945 cohort, rising to $55.8 \%$ for the 1979 cohort. Simultaneously, the percentage of Parliamentarians first elected in their 50s has steadily declined, particularly since 1955. But have trends towards a younger Commons continued?

The data in Tables 4 and 5 cast doubt on the post-war patterns identified by King (1981). First, the average age of MPs (by cohort) since 1979 has changed remarkably little. The average age of MPs elected in 2015 is 50.6, compared to 49.6 in 1979, and stayed within a two-year gap throughout the period. Moreover, the distribution of age across the range also shows little change since the late 70s. Turning to new entrants, and figures comparable to King's, 20 the data show very little change. The average age of first-elected MPs in 2015 
Table 4 Average age of MPs by cohort, 1979-2015

\begin{tabular}{llllllll}
\hline Election year & $\begin{array}{c}\text { Average } \\
\text { age of all MPs }\end{array}$ & $\mathbf{1 8 - 2 9}$ & $\mathbf{3 0 - 3 9}$ & $\mathbf{4 0 - 4 9}$ & $\mathbf{5 0 - 5 9}$ & $\mathbf{6 0 - 6 9}$ & $\mathbf{7 0 +}$ \\
\hline 1979 & 49.6 & 4 & 16 & 27 & 32 & 13 & 3 \\
1983 & 48.8 & 1 & 15 & 30 & 26 & 12 & 1 \\
1987 & 49.0 & 1 & 16 & 36 & 29 & 12 & 1 \\
1992 & 50.0 & 2 & 11 & 34 & 26 & 13 & $<1$ \\
1997 & 49.3 & $<1$ & 8 & 28 & 29 & 11 & 1 \\
2001 & 50.3 & $<1$ & 11 & 34 & 39 & 14 & 2 \\
2005 & 51.2 & $<1$ & 12 & 27 & 38 & 15 & 2 \\
2010 & 49.9 & 2 & 16 & 30 & 33 & 17 & 3 \\
2015 & 50.6 & 2 & 13 & 32 & 33 & 16 & 4 \\
\hline
\end{tabular}

Table 5 Average age of new/first-elected MPs, 1979-2015

\begin{tabular}{lccccccc}
\hline Election year & Average age of new MPs & $\mathbf{1 8 - 2 9}$ & $\mathbf{3 0 - 3 9}$ & $\mathbf{4 0 - 4 9}$ & $\mathbf{5 0 - 5 9}$ & $\mathbf{6 0 - 6 9}$ & $\mathbf{7 0 +}$ \\
\hline 1979 & 41.2 & 3 & 51 & 28 & 15 & 3 & 0 \\
1983 & 39.8 & 5 & 46 & 41 & 8 & 0 & 0 \\
1987 & 41.2 & 2 & 42 & 44 & 11 & 2 & 0 \\
1992 & 42.7 & 0 & 33 & 52 & 14 & 1 & 0 \\
1997 & 43.5 & 2 & 31 & 46 & 20 & 1 & 0 \\
2001 & 42.5 & 0 & 43 & 38 & 17 & 2 & 0 \\
2005 & 42.2 & 2 & 42 & 37 & 18 & 1 & 0 \\
2010 & 42.9 & 4 & 36 & 36 & 20 & 4 & 0 \\
2015 & 43.9 & 7 & 28 & 36 & 22 & 8 & 0 \\
\hline
\end{tabular}

Source: McGuinness (2010); PCUK 2015; age distribution rounded to nearest percentage.

is 44 and shows a slow but steady increase from an average age of 41 in 1979. But the age distribution shows, contra to King (1981), a declining percentage of MPs are first elected in their 30s: in 1979, 51\% of MPs first elected were in their 30s compared to $31 \%$ in 1997 and 28\% in 2015. And the percentage of MPs first elected in their 50s has grown from $15 \%$ in 1979 , to $20 \%$ in 1997 , to just under $22 \%$ in 2015.

The distribution also shows changes at the ends of the age spectrum. The 2015 election saw the largest percentage of younger (7\%) and older (8\%) MPs first elected, the latter the largest since 1945. At the younger end, Mhairi Black, a then 20-year old politics student, defeated one of Labour's most senior figures, 10 Douglas Alexander, becoming the youngest Member of Parliament in the modern era (Hawkins et al., 2015). Labour also has the four eldest MPs in its rank: 85year old Gerald Kaufman, the 'Father of the House' and Dennis Skinner, David 
Winnick and Paul Flynn also re-elected in their 80s. Despite changes at the 'poles', the 2015 data suggest that trends towards younger cohorts entering politics have been disrupted and that the Commons remains very much an institution dominated by the middle-aged.

\section{Conclusions}

Did the 2015 election provide a significant shake up in terms of who our representatives are, or did the 2015 election result in 'more of the same'? In several respects, the 2015 general election produced a more representative Parliament and two new records-there are now more women and BME MPs in the Commons than ever before. The gains were due in part to the record number of women and BME candidates standing in 2015, and importantly, where they stood-that is, in parties' target or winnable seats. While Labour had the highest percentage of women and BME candidates in their target seats, the number of SNP women and BME Conservative candidates in 'winnable' seats all contributed to the significant change we see in the Commons today.

Despite these gains in diversity, we see evidence of a narrowing of backgrounds across other social factors. MPs elected in 2015 were less likely to attend feepaying schools or to have attended Oxbridge, but $84 \%$ of MPs have university degrees, indicating a first degree is becoming a prerequisite to entry to the Commons. Moreover, the average (middle) age of MPs has changed little over the years and MPs are predominantly drawn from middle-class occupations. Changes and new records aside, the socio-demographic profile of the new Parliament is not significantly different, the archetypal MP continues to dominate the Commons.

Did the small parties make a difference? Did they offer up a different, more diverse profile of candidates? In terms of women the SNP certainly contributed to the increase in the number of women in the Commons, but in terms of members of BME communities, the SNP did not offer a more diverse slate of candidates than the two largest parties. In other respects, SNP candidates and MPs were not dissimilar from those from the larger parties. What of UKIP? UKIP's candidates were disproportionately white and male, but according to their own standards of representation (which do not give much priority to these two demographics), they were more like the general British public with fewer university-educated candidates standing. The typical UKIP candidate has a great deal in common with the typical UKIP voter (Ford and Goodwin, 35 2014), but the first-past-the-post electoral system means that despite their strong electoral showing, they did not have the opportunity to change who sits on the House of Commons benches. Thus, small differences in the candidate profiles offered up by the smaller parties reinforces Durose et al.'s (2013) 
notion of acceptable difference-that is - although candidates do diverge from the archetypal candidate on some factors, they conform on most others. This is true of both the larger and smaller parties.

Our efforts to document the socio-demographic profile of candidates and MPs in the Commons overtime point to two important issues going forward. First, the Equalities Act (2010) has yet to deliver a formal mechanism by which the political parties can agree to report on candidate diversity, and voluntary measures have not proved to be a sufficient remedy. And while the Act focuses on sex and racial/ethnic diversity, it does not expressly require parties report other factors (e.g. educational and occupational background, whether a candidate is from the local area), necessary in understanding the changing social profile of candidates/MPs. And, importantly, while some parties may be in a position to provide such data, others are not, quite simply lacking the resources and/or organisational capacity within the party.

Secondly and related, the lack of available data from the parties or otherwise, means that efforts to document who is selected and who is elected suffer from missing data. As we have shown here, missing data is more likely to come from UKIP and the Greens who fielded their largest number of candidates in 2015, but many of whom were paper candidates. The consequences of 'missingness' is that we may under- or over-estimate differences between the traditional and newer parties. But, it is not clear which direction missing data biases our estimates, or indeed if missing data is random or evenly distributed. In other words, would complete data on UKIP candidate's educational background conform to the general pattern we see here or result in a higher or lower percentage of university-educated candidates? Our approach has been to rely on information that candidates put into the public domain, which is not without limitations, but other means-for example, surveying candidates-also suffer from missingness via high rates of non-response. Going forward, efforts to understand who is selected and elected would benefit from complete and transparent candidate data and the political parties are integral to that effort.

\section{Acknowledgements}

This work was supported by the Leverhulme Trust (RPG-2013-175). The authors thank Begum Icelliler for her excellent research assistance.

\section{References}

Allen, P. (2013) 'Linking Pre-political Experience and the Career Trajectories of the 1997 General Election Cohort', Parliamentary Affairs, 66, 685-707. 
Allen, P. and Cairney, P. (2015) 'What Do We Mean When We Talk about the "Political Class"?', Political Studies Review, Advance Access Published on 12 May 2015. doi:10.1111/1478-9302.12092.

Best, H. and Cotta, M. (2000) Parliamentary Representatives in Europe, 1848-2000, Oxford, Oxford University Press.

Best, H., Cromwell, V., Hausmann, C. and Rush, M. (2001) 'The Transformation of Legislative Elites: The Cases of Britain and Germany since the 1860s', Journal of Legislative Studies, 7, 65-91.

Borchert, J. and Zeiss, J. (eds) (2003) The Political Class in Advanced Democracies: A Comparative Handbook, Oxford, Oxford University Press.

Cairney, P. (2007) 'The Professionalisation of MPs: Refining the 'Politics-Facilitating' Explanation', Parliamentary Affairs, 60, 212-233.

Cairney, P., Keating, M. and Wilson, A. (2015) 'Solving the Problem of the Social Background of the UK Political Class. Do Parties do things Differently in Westminster, devolved and European Elections'?, British Politics, 11, 1-22.

Campbell, R. (Forthcoming 2016) 'Representing Women Voters: The Role of the Gender Gap and the Response of Political Parties', Party Politics, 22 (5), 587-597.

Campbell, R. and Childs, S. (2010) 'Wags', 'Wives' and 'Mothers'... But what about Women Politicians?” Parliamentary Affairs, 63, 760-777.

Campbell, R. and Childs, S. (2015) 'All Aboard the Pink Battle Bus? Women Voters, Candidates and Party Leaders, and Women's Issues at the 2015 General Election', Parliamentary Affairs, 68, 206-223.

Campbell, R. and Cowley, P. (2014) 'What Voters Want: Reactions to Candidate Characteristics in a Survey Experiment', Political Studies, 62, 745-765.

Campbell, R. and Lovenduski, J. (2005) 'Winning Women's Votes? The Incremental 25 Track to Equality', Parliamentary Affairs, 58, 837-853.

Carnes, N. (2012). 'Does the Numerical Underrepresentation of the Working Class in Congress Matter?', Legislative Studies Quarterly, 37, 5-34.

Carroll, S. and Sanbonmatsu, K. (2013) More Women can Run: Gender and Pathways to the State Legislatures, Oxford, Oxford University Press.

Childs, S. and Webb, P. (2012) Sex, Gender and the Conservative Party, London, Palgrave Macmillan.

Criddle, B. (2010) 'More Diverse yet More Uniform: MPs and Candidates'. In Kavanagh, D. and Cowley, P. (eds) The British General Election of 2010, London, Palgrave, pp. 306-330.

Durose, C., Combs, R., Eason, C., Gains, F. and Richardson, L. (2013) ' “Acceptable Difference": Diversity, Representation and Pathways to UK Politics', Parliamentary Affairs, 66, 246-267.

Durose, C., Gains, F., Richardson, L., Combs, R., Broome, K. and Eason, C. (2011) Pathways to Politics, London, Equality and Human Rights Commission. 
Ford, R. and Goodwin, M. J. (2014) Revolt on the Right: Explaining Support for the Radical Right in Britain, Abingdon, Routledge.

Hansard Society (2012) Audit of Political Engagement 9, London, Hansard Society.

Hawkins, O., Keen, R. and Nakatudde, N. (2015) 'General Election 2015', House of Commons Library Briefing Paper, CBP 7186.

House of Commons (2010) 'Speaker's Conference (on Parliamentary Representation), Final Report', London, House of Commons, HC 239-1.

Jun, U. (2003) 'Great Britain: From the Prevalence of the Amateur to the Dominance of the Professional Politician'. In Borchert, J. and Zeiss, J. (eds) The Political Class in Advanced Democracies, Oxford, Oxford University Press.

Kelly, R. and White, I. (2016) 'All-women Shortlists', House of Commons Briefing Paper, CBP 5057.

Kenny, M. (2012) 'Less Male, Pale and Stale? Women and the 2012 Scottish Local Government Elections', Scottish Affairs, 80, 20-32.

King, A. (1981) 'The Rise of the Career Politician in Britain - And Its Consequences', 15 British Journal of Political Science, 11, 249-285.

Kirby, P. (2016) Leading People 2016: The Educational Backgrounds of the UK Professional Elite, London, Sutton Trust.

Kulich, C., Ryan, M. and Haslam, S. (2014) 'The Political Glass Cliff: Understanding How Seat Selection Contributes to the Underperformance of Ethnic Minority Candidates', 20 Political Research Quarterly, 67, 84-95.

Lovenduski, J. (2010) 'A Long Way to Go: The Final Report of the Speaker's Conference on Parliamentary Representation', Political Quarterly, 81, 438-442.

Mackay, F. and McAllister, L. (2012) 'Feminising British Politics: Six Lessons from Devolution in Scotland and Wales', Political Quarterly, 83, 730-734.

Mattozzi, A. and Merlo, A. (2008) 'Political Careers or Career Politicians', Journal of Public Economics, 9, 597-608.

McGuinness, F. (2010) 'Social Background of MPs', SN/SG/1528, House of Commons Library.

Norris, P. (ed.) (1997) Passages to Power: Legislative Recruitment in Advanced Democracies, 30 Cambridge, Cambridge University Press.

Norris, P. and Lovenduski, J. (1993) 'If Only More Candidates Came Forward': SupplySide Explanations of Candidate Selection in Britain', British Journal of Political Science, 23, 373-408.

Norris, P. and Lovenduski, J. (1995) Political Recruitment, Cambridge, Cambridge 35 University Press.

Oborne, P. (2007) The Triumph of the Political Class, London, Pocket Books.

Riddell, P. (1993) Honest Opportunism: The Rise of the Career Politician, London, Hamish Hamilton. 
Riddell, P. (1995) 'The Impact of the Rise of the Career Politician', The Journal of Legislative Studies, 1, 186-191.

Rush, M. (1994) 'Career Patterns in British Politics: First Choose Your Party', Parliamentary Affairs, 47, 566-582.

Särlvik, B. and Crewe, I. (1983) Decade of Dealignment: The Conservative Victory of 19795 and Electoral Trends in the 1970s, Cambridge, Cambridge University Press.

Sobolewska, M. (2013) 'Party Strategies and the Descriptive Representation of Ethnic Minorities: The 2010 British General Election', West European Politics, 36, 615-633.

Sturgis, P., Baker, N., Callegaro, M., Fisher, S., Green, J., Jennings, W., Kuha, J., Lauderdale, B. and Smith, P. (2016) 'Report of the Inquiry into the 2015 British General 10 Election Opinion Polls', London, Market Research Society and British Polling Council.

Van Heerde-Hudson, J. (ed.) (2014) The Political Costs of the 2009 British MPs' Expenses Scandal, Basingstoke, Palgrave.

Van Heerde-Hudson, J., Campbell, R., Goplerud, M. and Morucci, M. (2015) 'Patterned and Predictable? Pathways to Promotion, 1979-2010', Paper presented at the Elections, 15 Public Opinion and Parties Conference, Cardiff, Wales. 